\title{
THE ESSENCE OF EFFECTIVE AND EFFICIENT LEARNING
}

\author{
Baso Syafaruddin ${ }^{1 *}$, Dirhamzah ${ }^{2}$ \\ ${ }^{1}$ Department of Islamic Education, IAI As'adiyah Sengkang \\ Jl. Veteran No. 46 Sengkang, Kab. Wajo, Sulawesi Selatan, Indonesia. 90911 \\ *E-mail: safaruddinufe89@gmail.com \\ ${ }^{2}$ Department of Biology, Universitas Islam Negeri Alauddin Makassar \\ Jl. H.M. Yasin Limpo No. 36, Sulawesi Selatan, Indonesia. 92113
}

\begin{abstract}
To realize effective learning in terms of conditions and atmosphere as well as efforts to maintain it, the educator, as the guide, must be able to carry out the learning process optimally. Besides, to create an atmosphere and conditions that are effective in learning, there must be certain supporting factors such as the learning environment, the expertise of educators in teaching, adequate facilities and facilities as well as good cooperation between educators and students. These efforts are efforts to create and maintain conducive, optimal, and pleasant learning conditions and atmosphere so that the learning process can run effectively so that the learning objectives of achievement can be maximally achieved.
\end{abstract}

Keywords: educator, effective education, learning, student

\begin{abstract}
Abstrak: Untuk mewujudkan pembelajaran yang efektif ditinjau dari kondisi dan suasana serta upaya pemeliharaannya, maka pendidik selaku pembimbing harus mampu melaksanakan proses pembelajaran tersebut secara maksimal. Selain itu untuk menciptakan suasana dan kondisi yang efektif dalam pembelajaran harus adanya factor factor pendukung tertentu seperti lingkungan belajar, keahlian pendidik dalam mengajar, fasilitas dan sarana yang memadai serta kerjasama yang baik antara pendidik dan peserta didik. Upaya-upaya yang tersebut merupakan usaha dalam menciptakan sekaligus memelihara kondisi dan suasana belajar yang kondusif, optimal dan menyenangkan agar proses pembelajaran dapat berjalan secara efektif sehingga tujuan pembelajaran prestasi dapat dicapai dengan maksimal.
\end{abstract}

Kata Kunci: pendidikan efektif, pembelajaran, pendidik, siswa

\section{Introduction}

The learning process is a process that contains a series of implementations by educators and students based on a reciprocal relationship that takes place in an educational situation to achieve specific goals. This interaction or mutual relationship between educators and students is the main requirement for the learning process to take place. In reality, we see in schools; educators are often too active in the learning process. At the same time, students are made passive, so that the interaction between educators and students in the learning process is ineffective. If educators dominate the learning process, the effectiveness of learning will not be achieved. To create adequate learning conditions, educators are required to be able to manage the learning process that provides stimulation to students so that they are willing and able to learn. To be able to study effectively, everyone needs to know what learning means. Learning is an active act of understanding and experiencing something. Education is due to the interaction between stimulus and response. Therefore, the learning process occurs when children respond to stimuli given by educators. Also, achieving effective learning, students can be guided by educators from the previous knowledge they have stored in their memories and thoughts (cognitive) by using theory and learning methods appropriately. If this has not happened, the learning process will not run effectively and optimally without preparing several appropriate learning tools.

This paper discusses how to apply effective learning in terms of its true nature, so that knowledge will materialize, which results in optimal learning according to the objectives to be achieved.

\section{A. The essence of effective and efficient learning \\ 1. Understanding of Learning}


Learning is a change in personality as a new pattern in the form of chronic attitude skills or an understanding. Learning is essentially an endeavor, a process of change that occurs in an individual as a result of experience or the impact of the experience of interacting with the environment.

2. Understanding Effective and efficient

Effective is a change that brings certain effects, meanings, and benefits. Effective learning is characterized by its nature that emphasizes the active empowerment of students. Learning emphasizes the mastery of knowledge about what is done. Still, it stresses more on internalization, about what is done so that it is embedded and functions as a conscience and biological load and is practiced in life by students.

Efficient is the accuracy in doing something quickly, carefully without wasting time and efficiency. Effective learning is characterized by the ability to take advantage of the time, facilities, and infrastructure in the learning process that allows students to be able to understand the lesson well. It can be concluded that effective and efficient learning is a process of changing a person's behavior from the learning outcomes he gets from his own experiences and from his environment, which brings specific influences, meanings, and benefits.

The definition of learning according to experts, that learning can be defined as a process in which behavior is generated or changed through practice or experience. "Learning may be defined as the process by which behavior originates or is altered through training or experience." Thus, changes in behavior due to physical growth or maturity, fatigue, illness, or the influence of drugs are not considered learning. It can be concluded that, in general, learning is an activity carried out by educators in such a way so that the behavior of students changes for the better. Learning aims to help students gain various experiences, and with that experience, the behavior of students, which includes knowledge, skills, and values or norms that function as controllers of students' attitudes and behavior, increases, both in quantity and quality.

3. The essence of effective and efficient learning

The essence of effective and efficient learning is a teaching and learning process that is not only focused on the results achieved by students but how the learning process is effective and efficiently able to provide good understanding, intelligence, persistence, opportunity, and quality. It can give behavior change and apply it in their lives.

The primary role in teaching is to create a model of teaching activity that is strong and resilient. The point is teaching activities as environmental arrangement, classroom arrangement, in which students can interact and learn how to learn. Concerning the effectiveness of teaching, to achieve active learning, one crucial aspect is the problem of the methods used by educators in creating an energetic atmosphere. In the learning process with the lecture method, educators dominate the conversation while students are forced or even forced to sit, listen, and take notes. This process is not recommended. The lecture method must be reduced or even abandoned. The form of change from learning outcomes includes three aspects, namely: a) Cognitive elements include changes in terms of mastery of knowledge and development of skills/abilities needed to use that knowledge. b) Effective and efficient factors include changes in terms of mental attitudes, feelings, and awareness. c) The psychomotor part contains changes in the form of motor actions. The learning achievements of students obtained in the teaching and learning process at school can be seen and known from the scores of the semester exams, which are then stated in the report card score list.

\section{B. Effective and efficient learning characteristics}

Learning can be effective and efficient if it achieves the desired learning objectives by the achievement indicators. To find out how to get effective and efficient results in the learning process, it is essential to know its characteristics. The characteristics can identify effective and efficient learning: 1) Active learning, both mentally and physically. Mentally active is shown by developing intellectual abilities, critical thinking skills. Moreover, physically, for example, compiling the essence of the lesson, making maps, and others. Allah SWT said in QS An-Nahl: 78.

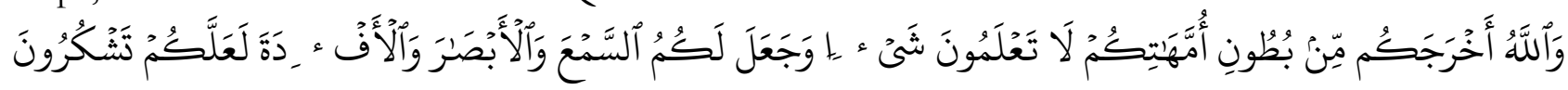


Meaning:

"And Allah brought you forth from the womb of your mother knowing nothing, and He gave you hearing, sight and heart, that ye may be grateful'.

2) Various methods, so that it is easy to attract the attention of students and the class to come alive. 3) Educators' motivation for classroom learning. The higher the inspiration of an educator will encourage students to be active in learning. 4) A democratic atmosphere in schools, namely by creating an environment of mutual respect, being able to understand the needs of students, being tolerant, allowing students to learn independently, respecting the opinions of others. 5) Lessons in school need to be linked to real life. 6) Conducive learning interaction, by giving freedom to look for themselves, so that it fosters a great sense of responsibility in their work and more confidence so that children do not depend on others. 7) Providing remedial and diagnosis of learning difficulties that arise, looking for causative factors, and providing remedial teaching as an improvement, if needed.

In addition to knowing the characteristics of effective and efficient learning, it is also necessary to understand how the characteristics of effective and efficient educators. This characteristic is useful for learning the skills and professionalism of an educator in carrying out effective and efficient learning. The characteristics are:

1. Having an interest in the subject

2. Have the ability to interpret the psychological atmosphere/climate of students

3. Fostering enthusiasm for learning

4. Having imagination in explaining

5. Mastering learning methods/strategies

6. Having an open attitude towards students

These characteristics mean that an educator must have higher insights or scientific fields than his students so that educators can instill things that are not known by their students, which in the end, the essence of learning, which initially does not know, becomes knowing. It is illustrated in the QS. An-Nahl: 43.

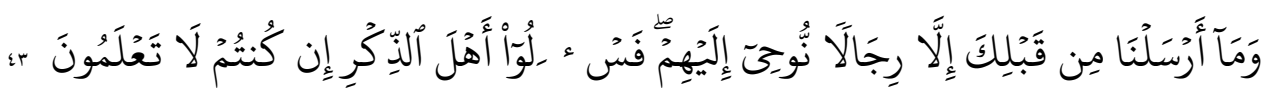

Meaning:

"And We did not send before you except the men to whom We revealed; So ask the people of knowledge if you do not know".

\section{Conditions and mood in the learning process}

Conditions for effective and efficient in the learning process

Educators, as guides, are expected to be able to create strategic conditions that can make students comfortable in following the learning process. In creating the right conditions, educators should pay attention to two things: first, internal conditions are conditions that exist in the students themselves, for example, health, safety, tranquility, and so on. Second, external conditions, namely conditions that exist outside the human person, for instance, the cleanliness of the house, lighting, and other physical ailments. To be able to study effectively and efficiently, a good and regular physical environment is needed. For example, the study room must be clean. There are no smells that can interfere with learning concentration; the place is bright enough, not dark, and does not interfere with the eyes, the necessary means of adequate learning, or complete. In realizing effective and efficient learning conditions, it is essential to take the following steps:

a. Involving students actively

Teaching is guiding the learning activities of students so that they want to learn. Thus the activities of students are needed in learning activities. The learning activities of students can be classified into several things, including:

1. Visual activities, such as reading, writing, doing experiments, etc.

2. Oral activities, such as telling stories, questions, and answers, etc. 
3. Listening activities, such as listening to educators 'explanations, listening to educators' directions, etc.

4. Movement activities, such as practicing at the practice site.

5. Writing exercises, such as composting, writing letters, writing papers, etc.

The learning activities of students in the class should involve more students or pay more attention to the actions of students. Here is how to increase student engagement:

1. Increase the participation of students in learning activities by using various teaching techniques.

2. Provide explicit and appropriate learning material through the learning objectives.

3. Try to make learning more attractive to students. For this reason, educators must know the interests of students and relate them to learning materials.

b. Attract students' interest and attention

The condition of effective and efficient learning is the interest and attention of students in learning. Curiosity is a characteristic that is relatively fixed in a person. This interest has a significant effect on learning because, with interest, someone will do something as his interests. On the other hand, without someone's claim, it is impossible to do something. The involvement of students in learning is closely related to the nature, talents, and intelligence of students. Learning that can adjust the personality, skills, and brightness of students is learning that is in demand.

c. Generating student motivation

The motive is a kind of power within a person that can encourage him to do something. In contrast, motivation is a process to activate motives into actions or behavior to meet needs and achieve goals. The task of educators is how to motivate students so that they want to learn. Here are some ways to encourage students:

1. Educators try to create competition among their students to improve their learning achievement;

2. At the beginning of learning activities, educators should first convey to students about the goals to be achieved in the learning so that students are provoked to participate in achieving these goals.

3. Educators try to encourage students to learn to achieve learning goals.

4. Educators should provide many opportunities for students to achieve success with their efforts;

5. Educators always try to attract students' interest in learning.

6. Give assignments often and give scores as objectively as possible.

d. Providing individual student services

Providing individual student services is not solely aimed at individual students, but can also be addressed to a group of students in a particular class. Individual learning systems or private learning have recently been quite prevalent through private lessons and through educational institutions that are specialized in providing personal services. In a complete learning system, personal service is an activity that must be carried out. All students, without exception, must understand each sub-subject matter presented. Therefore, incomplete learning, the subject matter should not be continued before the material being taught can be absorbed by all students.

e. Preparing and using various media in learning

Teaching aids/learning media are tools that are used by educators when teaching to help clarify the subject matter presented to students and prevent verbalism in students. Because learning that uses many verbalisms will undoubtedly be boring, conversely, learning will be more interesting if students feel happy and happy every time they receive a lesson from their educators.

In preparing and using media or props, several things need to be considered, as follows:

1. The props used should be able to increase the attention of students to the subject matter that is being presented.

2. The props selected should be following the maturity and experience of students as well as individual differences in the group.

3. The equipment chosen should be appropriate, adequate, and easy to use.

2. The learning atmosphere is effective and efficient 
In connection with the teaching and learning process, educators should be able to direct and guide students to be active in teaching and learning activities to create a good interaction between educators and students and students and students. To create a classroom atmosphere that supports the teaching and learning process that can help the effectiveness of the teaching and learning process, namely:

a. Call each student by name,

b. Always be polite to students,

c. Ensure that you do not show favoritism towards sure students.

d. Plan what you will do in each lesson

e. Tell the students what you want to achieve in this lesson,

f. In some way, involve each student during the study.

g. Provide opportunities for students to talk to each other

h. Be consistent in dealing with students.

The adequate class organization is needed to create an atmosphere that can foster a passion for learning, improve student-learning achievement, and make it more possible for educators to provide guidance and assistance to students in learning. In this case, several conditions for effective and efficient implementation of the learning process will be described:

1) Fun learning atmosphere

A pleasant learning atmosphere makes learning run effectively and efficiently. If the learning atmosphere is fun, students will be more relaxed, free from pressure, safe, attractive, awakening interest in learning, full involvement, attention of students poured out, enjoyable learning environment. For example, the class is bright, seating arrangements are free for students to move), excited, happy feelings, high concentration.

2) Free atmosphere

A free or open (permissive) atmosphere is freedom for students to speak and argue following the objectives of the learning process so that by doing so; students will not feel pressure, fear, shame, and others towards educators and fellow students.

3) Selection of appropriate teaching media and methods

Educators are required to be able to own and use teaching media by the material to be presented. They are required to be able to use stimulant-teaching methods to liven up the teaching atmosphere properly.

\section{Conclusion}

The learning process is a process that contains a series of implementations by educators and students on the basis of a reciprocal relationship that takes place in an educational situation to achieve certain goals. This interaction or reciprocal relationship between educators and students is the main requirement for the learning process to take place. In essence, effective learning is a teaching and learning process that is not only focused on the results achieved by students, but how an effective learning process is able to provide good understanding, intelligence, perseverance, opportunity and quality and can provide behavior change and apply it in their lives. To realize effective learning in terms of conditions and atmosphere as well as efforts to maintain it, the educator as the guide must be able to carry out the learning process optimally. In addition, to create an atmosphere and conditions that are effective in learning, there must be certain supporting factors such as the learning environment, the expertise of educators in teaching, adequate facilities and facilities as well as good cooperation between educators and students. These efforts are efforts to create and maintain conducive, optimal and pleasant learning conditions and atmosphere so that the learning process can run effectively so that the learning objectives of achievement can be maximally achieved.

\section{References}

Djiwandono SEW. 2002. Psikologi Pendidikan, Jakarta: PT Grasindo

Gulo, W. 2002. Strategi Belajar Mengajar. Jakarta: PT Grasindo.

Hamalik O. 2002. Kurikulum dan Pembelajaran. Jakarta: PT. Bumi Aksara. 
Mulyasa E. 2003. Menjadi kepala sekolah profesional: dalam konteks menyukseskan MBS dan KBK, Bandung: Remaja Rosdakarya,

Nawawi H. 1989. Organisasi Sekolah dan Pengelolaaan Kelas sebagai Lembaga Pendidikan, Jakarta: Haji Masagung

Prayitno. 2009. Dasar teori dan praksis Pendidikan. Jakarta: Grasindo.

Purwanto N. 1996. Psikologi pendidikan remaja. Bandung: Remaja Rosda Karya

Rianto M. 2007. Pengelolaan Kelas Model Pakem, Jakarta: Dirjen PMPTK

Rosyada D. 2004. Paradigma Pendidikan Demokratis: sebuah Model Pelibatan Masyarakat dalam Penyelenggaraan Pendidikan, Jakarta: Prenada Media.

Santrock JW. 2008. Educational Psychology, Terj.Tri wibowo B.S, Psikologi Pendidikan, Jakarta: Prenada Media Group.

Semiawan C. 1990. Pendekatan Keterampilan Proses, Jakarta: Gramedia

Slameto. 1995. Belajar dan Faktor - Faktor Belajar yang Mempengaruhi, Jakarta: PT Rineka Cipta.

Soemanto W. 1998. Psikologi Pendidikan: Landasan Kerja Pemimpin Pendidikan (Edisi Baru). Jakarta: PT Rineka Cipta.

Sudjana. 2004. Manajemen Program Pendidikan Untuk Pendidikan Nonformal dan Pengembangan Sumber Daya Manusia, Bandung: Falah Production.

Syafaruddin dan Irwan N. 2005. Manajemen Pembelajaran, Jakarta: Penerbit Quantum Teaching. 